\title{
BUILT HERITAGE IN THE 2020 EARTHQUAKES IN ZAGREB AND PETRINJA, CROATIA: EXPERIENCE AND CONSEQUENCES
}

\author{
JOSIP GALIĆ, DAVOR ANDRIĆ, LUCIJA STEPINAC \& HRVOJE VUKIĆ \\ Department of Architectural Technology and Building Science, University of Zagreb, Croatia
}

\begin{abstract}
Croatia is a seismically active country, with recorded devastating earthquakes - among which is the Zagreb earthquake of 1880, when many buildings have been destroyed. Since that time 140 years have passed, and little has been done to prepare the city and its buildings for the return of a similar event, last year's quake found Zagreb rather unprepared. The same year an even more massive earthquake hit Petrinja. An overview of observed damage caused directly and by the aftermaths of the earthquakes in Croatia: Zagreb in March and Petrinja in December 2020 is given. Most of the damage is recorded on historical buildings with brick walls and wood floors and roofs, but some damage on contemporary structures is also noted. Most of the damage is found on old buildings; most of them are part of Zagreb historical centre and are in the protected heritage area or are listed as protected heritage buildings. These include damage like cracks in walls, collapse of unsupported walls, and parts of architectural details, chimneys, gable walls as well as damaged or collapsed vaulted ceilings, wood floor structures and roofs. Buildings of the modern period have sustained damage as well. Several typical types of damage stand out: infill walls of concrete frames damaged due to different flexibility, columns damaged mostly due to insufficient reinforcement, and steel to concrete connection details failure. Main problems for reconstruction and retrofitting are of financial nature, cultural asset status of large number of damaged buildings, scale, and complexity of some buildings mostly in Zagreb, and sustainability of settlements in Sisak-Moslavina County in case of Petrinja earthquake. Based on these observed phenomena, a set of appropriate approaches to the post-earthquake renewal is proposed including techniques for retrofitting depending on the desired level of quake proofing.
\end{abstract}

Keywords: earthquake, Zagreb, Croatia, Petrinja, masonry, damage, heritage.

\section{INTRODUCTION}

Croatia has a long history of intense earthquakes all across the country, with some notable being the Dubrovnik earthquake in 1667, Međimurje earthquake in 1738, the great Zagreb earthquake in 1880, Turjak earthquake in 1898 and Vinodolski earthquake in 1916 [1]. Recent history records earthquakes of magnitude 6 throughout the 20th century, most of them on the Croatian south, like M 6.2 earthquake in Imotski in 1942, M 6.1 in Makarska, in 1962, and M 6.0 in Ston-Slano in 1996 [2]. Other notable earthquakes in countries of former Yugoslavia include devastating earthquakes in Skopje in 1963, Banja Luka in 1969, and Montenegro in 1979 that severely impacted Dubrovnik city in the Croatian south.

Regulations regarding earthquakes are usually enacted only after the event takes place when people become more aware of the problem. For instance, after the earthquake in Zagreb in 1880 and the earthquake in Ljubljana in 1895, residential and public buildings are built as brick masonry, instead of two-layer stone walls, obeying the maximum height limit set at five floors $(20 \mathrm{~m})$. The walls are also braced by metal clamps at the floor plane. Ordinance on temporary technical regulations for construction in seismic regulations [3] was enacted after the Skopje earthquake in 1963, and after the Ulcinj earthquake in 1979, Ordinance on technical standards for the construction of buildings in seismic areas [4] was enacted. The most notable Croatian codes relating the rules of seismic design are given in Table 1. 
Table 1: Important Croatian codes relating the rules of seismic design.

\begin{tabular}{|l|l|}
\hline Year & Codes and regulations \\
\hline 1947 & Interim technical regulations \\
\hline 1964 & $\begin{array}{l}\text { Ordinance on temporary technical regulations for construction in seismic } \\
\text { regulations [3] }\end{array}$ \\
\hline 1981 & $\begin{array}{l}\text { Ordinance on technical standards for the construction of buildings in } \\
\text { seismic areas [4] }\end{array}$ \\
\hline $2007-2009$ & Technical regulations for concrete [5] and masonry [6] structures \\
\hline 2012 & Modern technical regulations - EN 1998 \\
\hline
\end{tabular}

The latest earthquakes in Zagreb and Petrinja, in 2020 and 2021, have revealed many problems. Three stand out: (1) the cities and the state of Croatia are unprepared to react promptly to the disaster; (2) the army no longer has the efficient construction operative, and (3) large number of buildings are of low seismic resistance - about $30 \%$ of the building stock predates 1963, until when residential and public buildings were mostly built as masonry.

Most of the buildings were poorly maintained and the upgrades were not comprehensive - they were mostly performed without seismic improvements. Until 1941 the construction of the buildings was of acceptable quality, and number of storeys was appropriate but inadequate layout of the load-bearing structures was present. After the World War II, construction significantly worsened, building structures with walls in only one direction, and often surpassing the set limits for masonry buildings. There was also a significant problem of illegal construction in Croatia - that was later legalised - which was not accompanied by appropriate technical documentation and technically sound construction. Another problem that helped generate and further worsen the situation, especially the neglect for older buildings, was inappropriate criteria for heritage preservation of historical buildings. Too often, everything was considered a protected heritage asset that needed to be preserved as much as possible, blocking the potential upgrades that could have brought necessary seismically improvements with them.

\subsection{The Zagreb earthquake}

The city of Zagreb stands at the contact of large tectonic units: Alps in the northwest, Pannonian Basin in the east, and Dinarides in the south. Due to the pushing and/or subsiding of individual tectonic units, the lithosphere breaks, and faults are created as the source of seismic activity. The area of the city of Zagreb is influenced by the zone of the Žumberak-Medvednica-Kalnik fault. The strongest known earthquake occurred on November 9, 1880, at 07:03. Estimated magnitude was 6.0-6.5, and less intense earthquakes shook the area in 1905 and 1906 [7]. Zagreb had 30,000 inhabitants and about 2,500 residential buildings of which 1,400 were damaged or demolished.

On Sunday, March 22, 2020 at 6:24 am M 5.5 earthquake at a depth of $10 \mathrm{~km}$ and intensity VII according to the EMS scale with the epicentre in Markuševac, approx. $9 \mathrm{~km}$ to the centre of Zagreb, hit the city killing one person - a 15-year-old girl. In the period from March 22 to November 22, 2020, there were over 200 earthquakes of magnitude greater than or equal to M 1.3 [8]. The largest of these aftershocks was of M 4.9 about 40 minutes after the main quake. 
According to the data of the Seismological Service, accelerographs at a distance of $8.2 \mathrm{~km}$ and $11.7 \mathrm{~km}$ from the epicentre recorded the peak acceleration of the ground soil $\mathrm{a}_{\max , \mathrm{A}}=0.22 \mathrm{~g}$ and $\mathrm{a}_{\max , \mathrm{B}}=0.20 \mathrm{~g}$ for the M 5.5 earthquake, while the $\mathrm{a}_{\max , \mathrm{A}}=0.07 \mathrm{~g}$ and $\mathrm{a}_{\max , \mathrm{B}}=0.04 \mathrm{~g}$ were recorded for the M 4.9 earthquake [9].

In the period from March 22, 2020, till July 01, 2020, rapid damage inspections were conducted according to EMS classification under the guidance of Croatian Centre for Earthquake Engineering [10]. The Same Centre created a manual and a form - by adapting the existing form used in Italy - for conducting the inspections [11]. Buildings were issued a green, orange (yellow), or red label according to the estimated scale of sustained damage (Fig. 1).
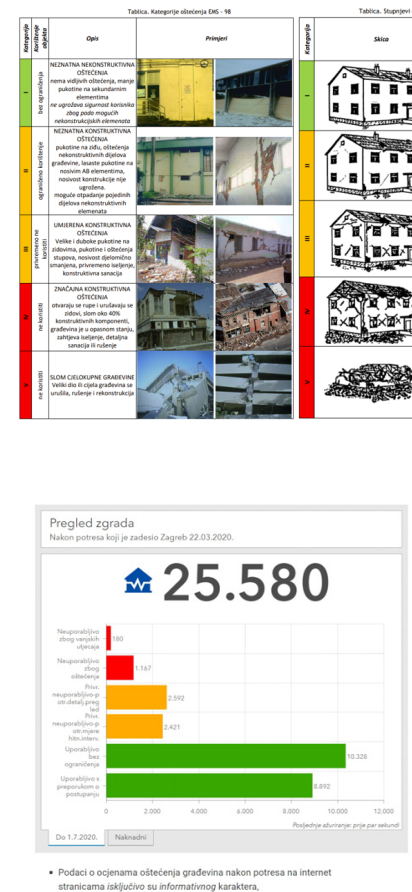

(b)

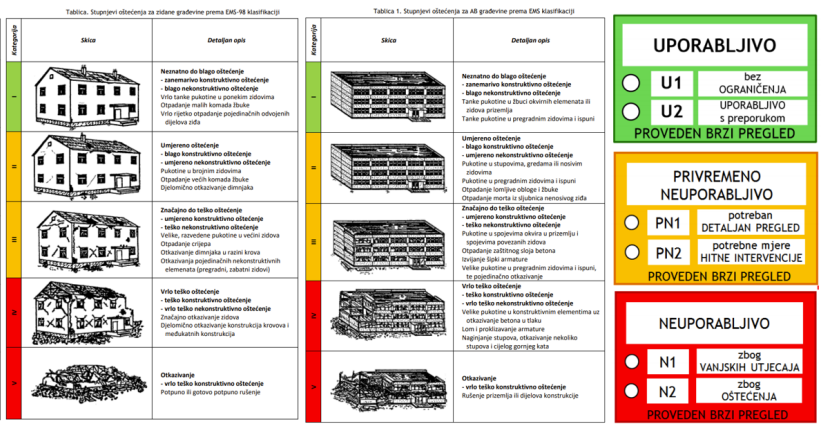

(a)

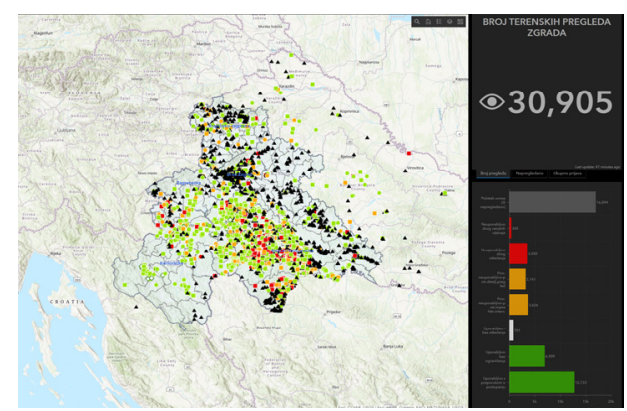

(c)

Figure 1: Damage inspections. (a) Manual for rapid damage assessments [11] and total number of inspections (b) after the Zagreb earthquake, and (c) after the Petrinja earthquake [10].

\subsection{The Petrinja earthquake}

The tectonics of the Pokupsko-Petrinja-Sisak area is caused by the continuous movement of the Adriatic microplate to the north, due to which there is great stress and activation of individual faults at the contact of the Dinarides and the Pannonian Basin. Since the acquisition of the first seismographs in Croatia in 1909, up until 2019 1,364 earthquakes were detected in the vicinity of Petrinja. The strongest known earthquake of 5.8 magnitude took place on October 8, 1909 in Pokupsko. By analysing that particular earthquake, seismologist and geophysicist Andrija Mohorovičić made one of the greatest discoveries in 
seismology - the boundary between the Earth's crust and the mantle - the Mohorovičić discontinuity [12].

On December 28, 2020, at 6:28 am the first M 5.0 earthquake occurred with the epicentre in Petrinja (about $50 \mathrm{~km}$ SE from ZG). On the same day, there were two more earthquakes, an M 4.7 at 07:49 am, and an M 4.1 at 07:51, with a series of weaker ones. On the next day, December 29, 2020, at 12:19 pm, the strongest earthquake M 6.2 occurred with the epicentre $3 \mathrm{~km}$ southwest of Petrinja at a depth of $10 \mathrm{~km}$. It was the strongest earthquake recorded by instruments in Croatia since 1909. Seven people were killed, 5 of them in the village of Majske Poljane [13]. Thus, the earthquake of Petrinja activated the system of faults in the underground of the wider Sisak, Petrinja and Glina area. After the main earthquake until January 28, 2021, 622 more earthquakes of magnitude greater than 2.0 were recorded.

\section{CHARACTERISTIC DAMAGE}

Most of the damaged buildings were built before 1964, which means that they were built before the first true seismic regulations in Croatia. The largest number of damaged buildings is among old masonry buildings. Buildings without concrete ceilings sustained greater damage compared to masonry buildings with concrete ceilings. Collapses and other damage are more pronounced in buildings that have not been properly maintained and on the buildings that were inappropriately reconstructed. The greatest amount of damage in concrete buildings was present in buildings with frame structures, mostly to non-structural elements like infill walls, but also to structural elements like columns. Modern buildings built after 1981 in general did not sustain significant damage except in some isolated cases - as the result of errors in design or inadequate execution of works. Steel structures were mostly undamaged, except in some cases where the bracings gave way. Wooden structures would have had breakage if they had already been damaged or had inappropriately executed connections details or unsuitable structural systems (roofs).

\subsection{Problems and damage to masonry structures}

Several main deficiencies and reasons for damage and collapses of masonry buildings were noted. First one was the extremely poor quality of construction materials and thus low lateral resistance of load-bearing walls. Shear strength is not realistically higher than $\mathrm{f}_{\mathrm{v} 0}=$ $0.10 \mathrm{MPa}$. Second one is that the structural integrity of the buildings was insufficient, causing local failures, separation, and collapse of structural elements. Generally, the connections between the ceiling structure and the walls do not exist or is extremely weak acting only through friction. The walls are usually not held transversally by other walls (out of plane problems), and the connection of longitudinal and transversal walls is exclusively done by a masonry connection which is inadequate due to its weak properties. The only additional connection is sometimes made by the built-in ties that were often found to be damaged. The roofs of the buildings were mostly dilapidated, and their structures were not properly connected with the masonry structure. Thirdly, inadequate load-bearing wall layout and inappropriate geometry is often the issue - which in most cases manifests in openings that are too large, buildings that have too many storeys, and systems with oneway ceilings that leave lateral walls unladen by the weight of the ceilings further increasing the number of cases of damage.

Masonry structures sustained several characteristic types of damage (Fig. 2). These include damage and collapse of unsupported protrusions like chimneys, gables, facades, towers and alike. Further, damage to brick vaults and wooden ceilings were often present as 
well as separation, cracking and collapse of the walls. Common damage to masonry was in form of slipping or diagonal tensile/shear failure.

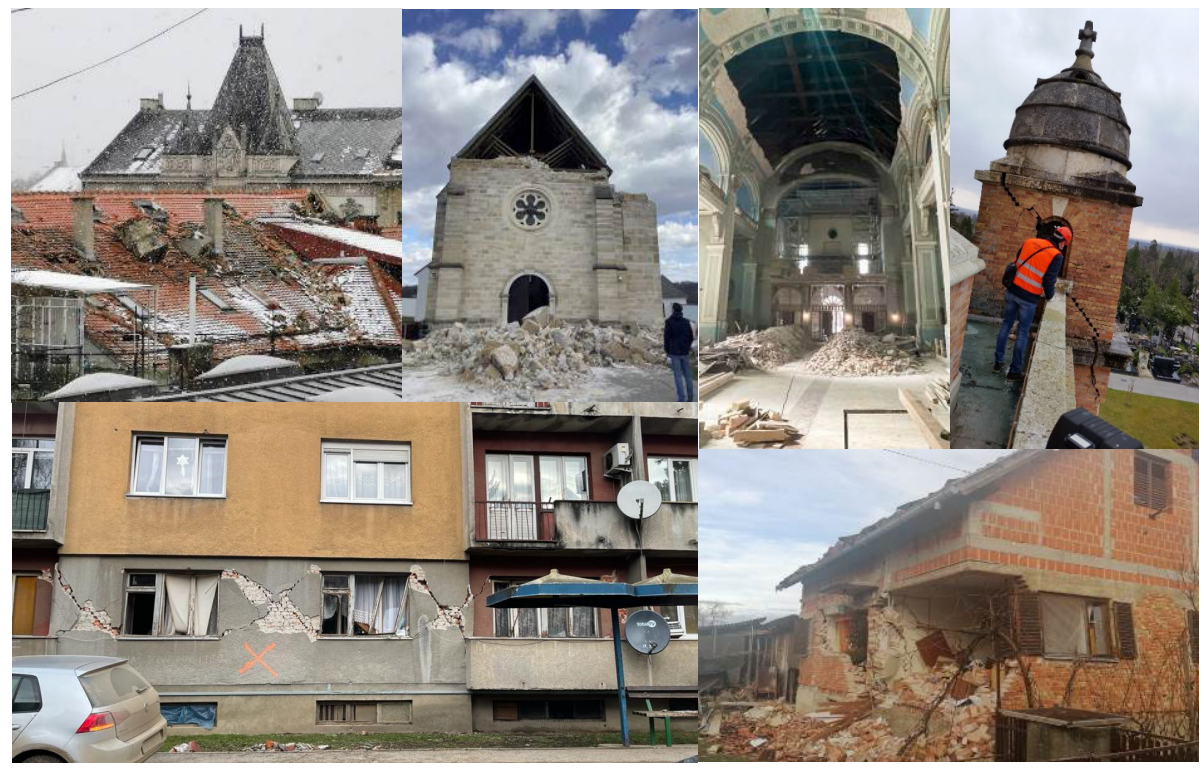

Figure 2: Damage to masonry structures. (Source: Authors.)

\subsection{The damage to reinforced concrete structures}

Damage to concrete structures (Fig. 3) was less spread, but still there were some reoccurring types of damage that they have sustained. Concerning the reinforced concrete frame structures, damage manifested mostly as partition and infill walls failing due to the flexibility of the frames and their horizontal displacements. Typical column damage was caused by sparsely spaced or missing reinforcement ties. Damage to the joints of steel and concrete girders on concrete columns and walls was also observed.

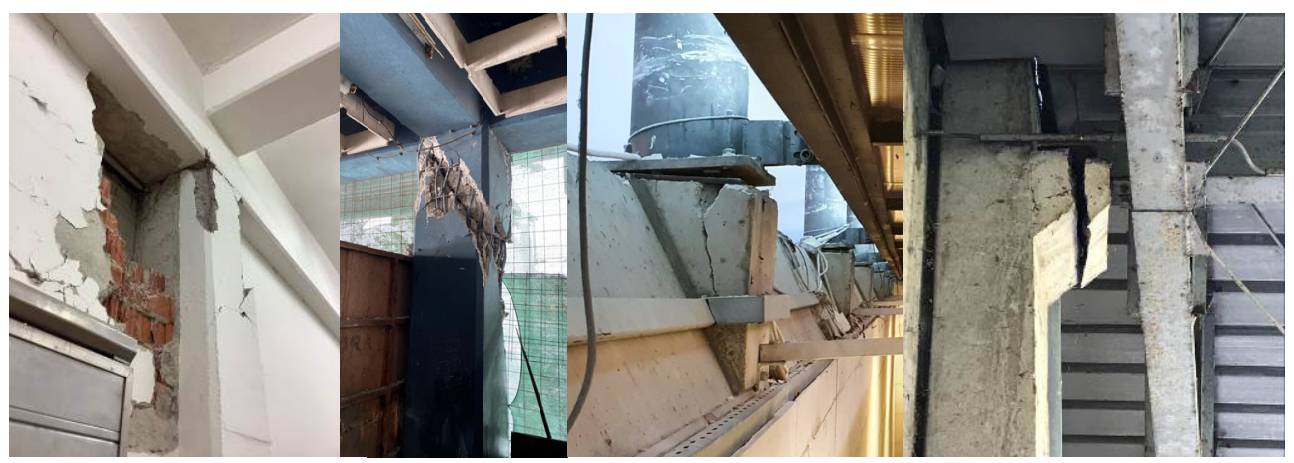

Figure 3: Damage to RC structures. (Source: [10] and authors.) 


\subsection{Geotechnical problems}

Soil liquefaction was present in the Sisak-Moslavina area during the Petrinja earthquakes. The decrease in the strength of sandy soil caused the structures to crack where the ground under their foundation sunk. The expelling of soil with fluid-like behaviour and water to the surface in the form of geysers was observed, as well as the occurrence of large sinkholes due to the fact that below the alluvial sediments there are limestone rocks, eroded by the long-term action of groundwater. In this contact zone, the finer fraction is washed away, and cavities are formed, notably in places like Mečenčani and Donji Kukuzari. Landslides mainly displacement of previously active landslides - also occurred where loss of shear strength was caused due to inertial forces. Cracks and subsidence of the embankment was present as well [14].

\section{THE RECONSTRUCTION OF THE BUILDINGS IN ZAGREB AND PETRINJA AREAS}

Many buildings were damaged or demolished in the Zagreb and Petrinja earthquakes and costly and time-consuming renovations followed. The Law on Reconstruction of earthquake-affected areas [15] has been passed, which envisages: that all public buildings and protected cultural asset buildings would be completely renovated with the costs to be borne by the owner; demolished private houses were to be renovated by the state covering the $100 \%$ of costs - but only the necessarily "usable" portion of the houses; and for the damaged private residential/business buildings, the state and the cities would co-finance up to $80 \%$ of the costs of structural retrofitting and improvements that would reach up to the $50 \%$ of the HRN EN 1998 norm.

\subsection{Main problems of reconstruction}

Several problems emerged after the post-earthquake assessments of damage. First one was how to secure an amount of money needed for renovation? Further, in Zagreb, a large number of damaged buildings are in the historically protected area or listed as individual cultural asset. Further on, in Zagreb case, some of the buildings are relatively large, and their structural improvement is quite complicated to implement because it requires the evacuation of residents and high associated costs. In Sisak-Moslavina County on the other hand, the main problem is how to ensure the sustainability of settlements since many of them are facing decades-long depopulation.

The Faculty of Architecture has issued two manuals in the field of seismic improvement of old masonry buildings in order to fill the informational void that emerged after the earthquake: Techniques for the Repair and Strengthening of the Masonry Buildings [16], and Manual for Seismic Retrofitting of the Existing Masonry Buildings [17]. Subsequently, a third manual called Urban Renewal was also published [18].

In the Techniques for the Repair and Strengthening of the Masonry Buildings, an overview of main causes of damage and failure of masonry structures along with the overview of conventional and special techniques for retrofitting and reinforcement of masonry buildings is given. It also includes an overview of the most commonly used techniques for retrofitting and reinforcement of reinforced concrete buildings. It is supplemented with information on the process of creating a project for the retrofitting and strengthening of the load-bearing structure of existing buildings (Fig. 4). 

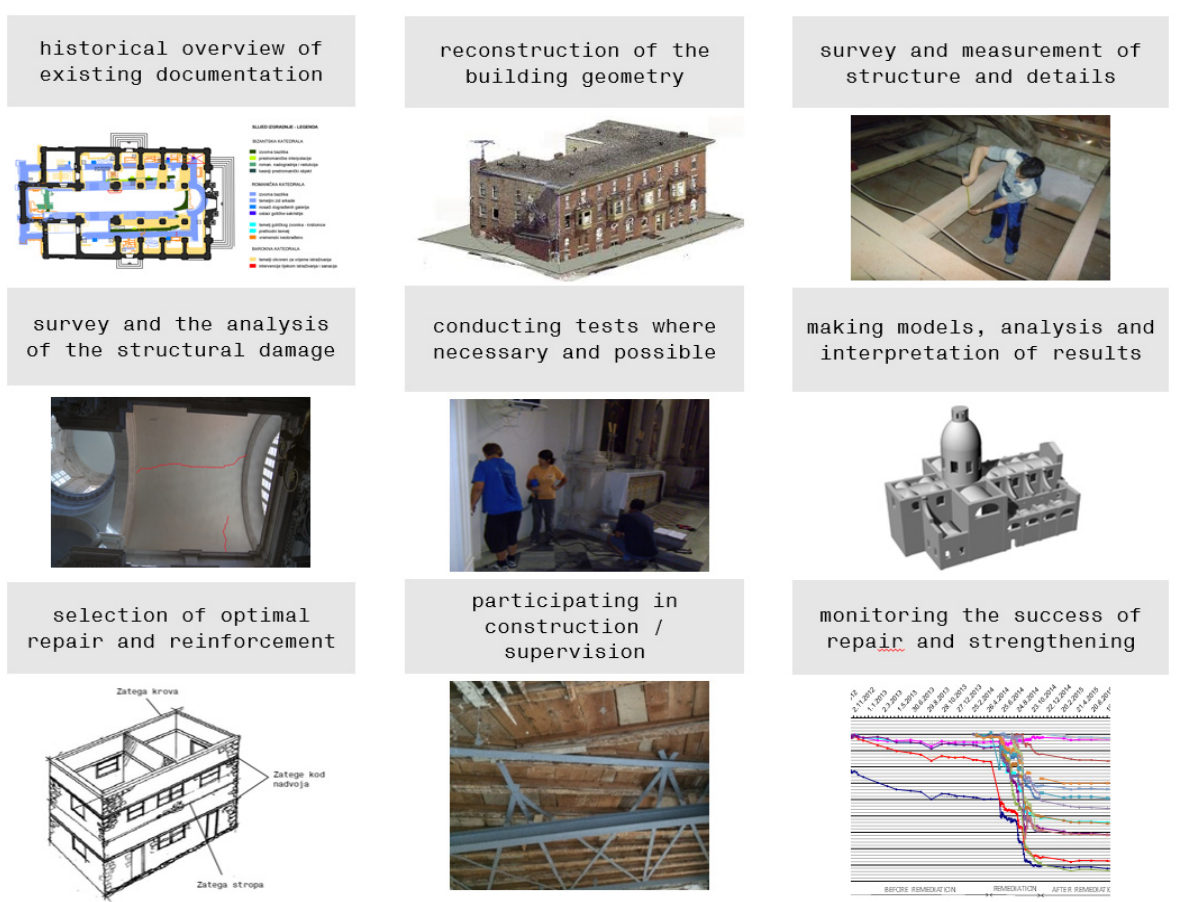

Figure 4: The process of making a project for the retrofitting and strengthening of a building [16].

In the Manual for Seismic Retrofitting of the Existing Masonry Buildings a concrete case of a typical Zagreb historical lower-town building with masonry structure and wood ceilings (Fig. 5) was used to demonstrate different levels of interventions in accordance with the conclusions of the expert group at the Faculty of Civil Engineering, University of Zagreb, organised in cooperation with the Croatian Chamber of Civil Engineers. Levels range from basic retrofitting (Fig. 6), basic strengthening (Fig. 7), overall strengthening of existing structure (Fig. 8) all the way to the more invasive and overall reconstruction (Fig. 9). These are coupled with the cost estimate for each level with all the prices for necessary works - total estimated prices are given in Table 2.
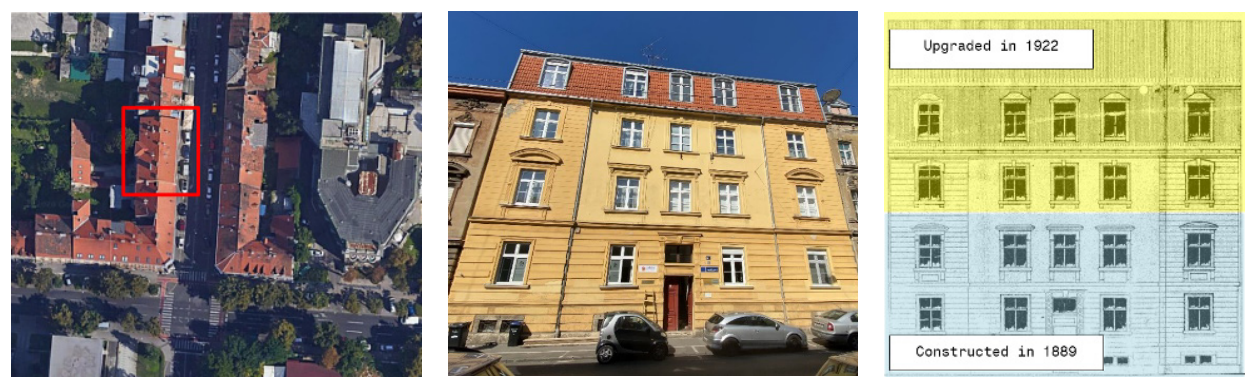

Figure 5: Case building for the simulation of retrofitting and reinforcement levels, Kačićeva 22, Zagreb, Croatia [17]. 


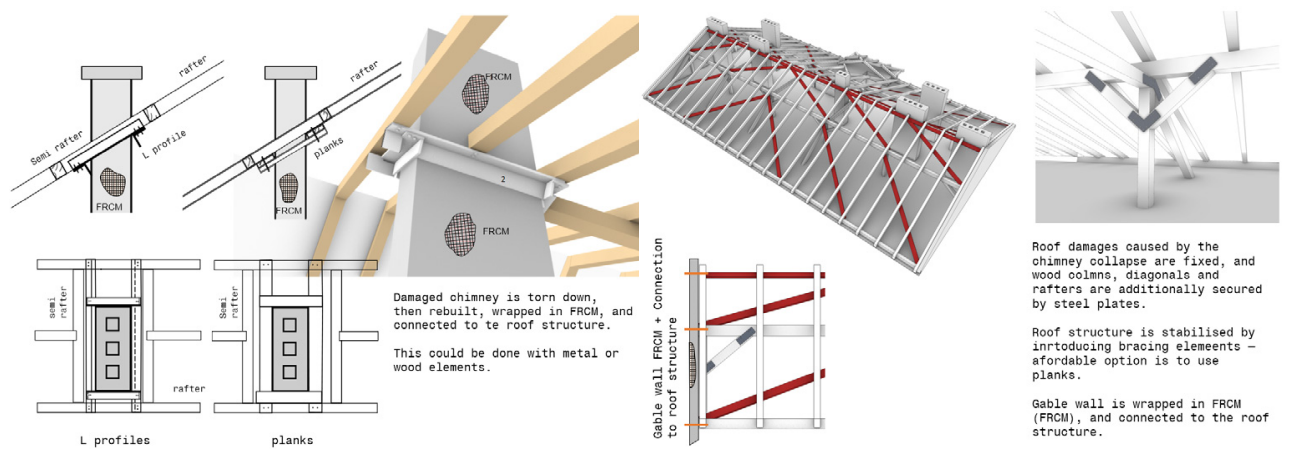

Figure 6: First level - basic retrofitting: chimneys, gable walls are rebuilt, roof structure is stabilised, and roof floor is rigidised and connected to the walls [17].
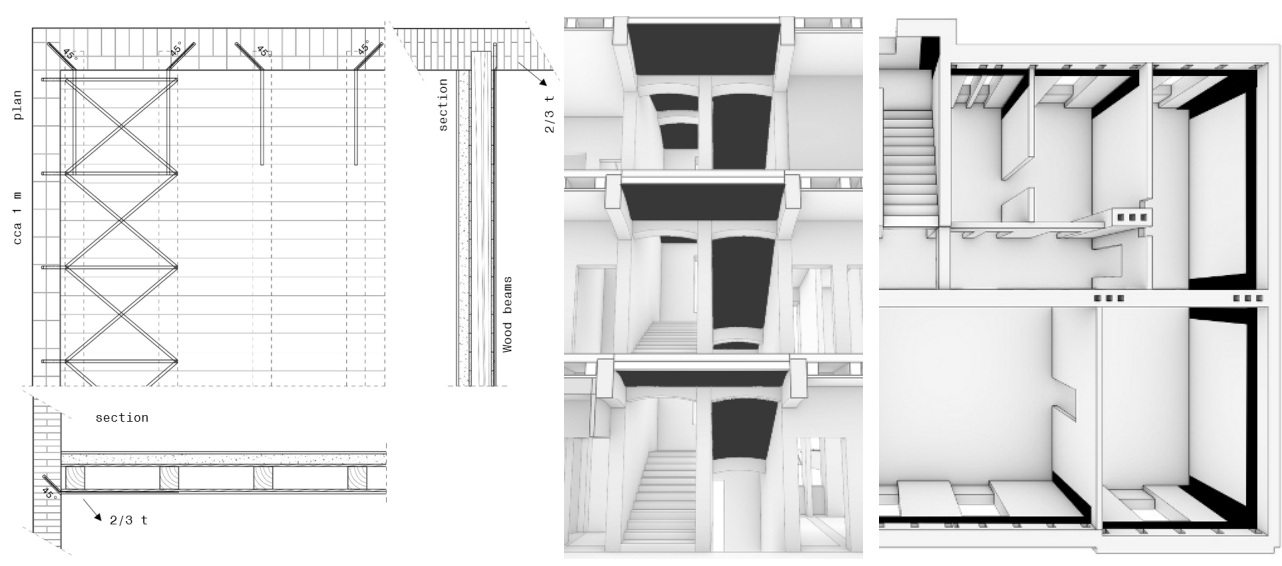

Figure 7: Second level - same as first, but with addition of all floors being connected to the walls that are partially reinforced with FRCM [17].

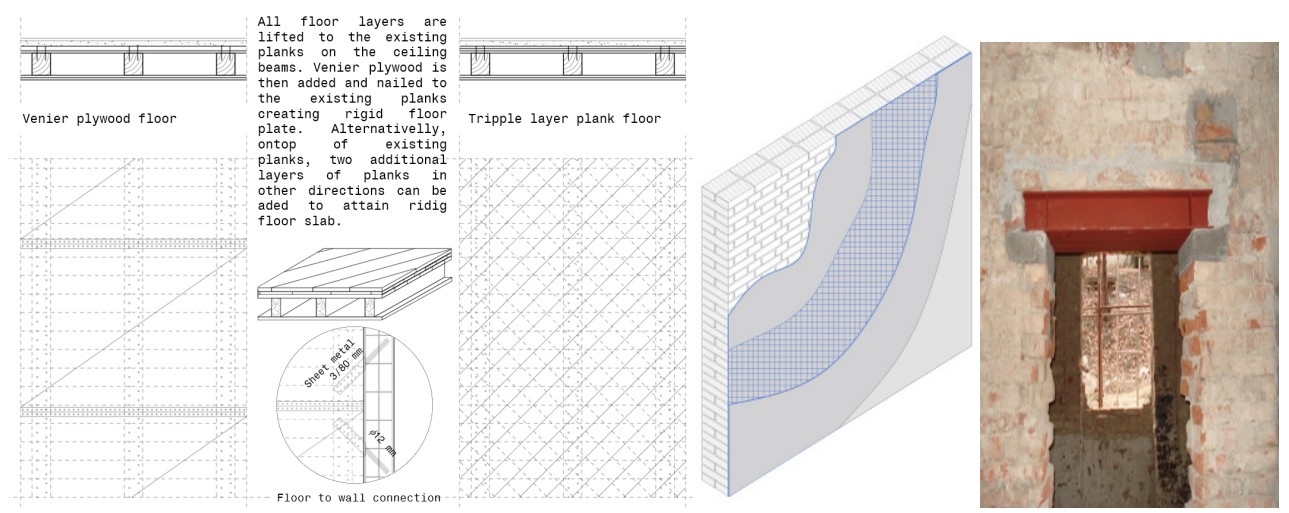

Figure 8: Third level - all floors are rigidised and connected to the walls that are completely reinforced with FRCM and steel lintels [17]. 

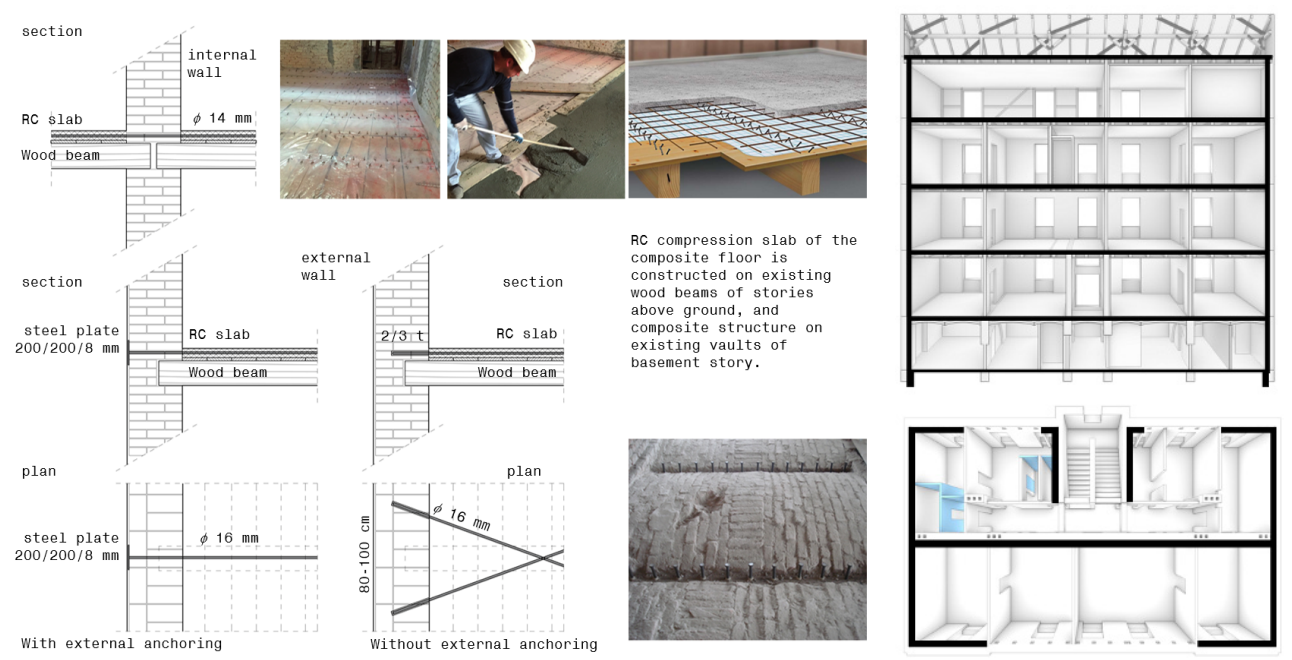

Figure 9: Fourth level - Reinforced concrete walls are inserted into floor plan and all floors are fitted as composite floors [17].

Table 2: Cost estimate for case building in downtown Zagreb with prices in Euro at the time of the earthquake [17].

\begin{tabular}{|c|c|c|c|c|}
\hline & Level & Description & $\begin{array}{c}\text { Total } \\
\text { cost in } \\
€\end{array}$ & $€ / \mathrm{m}^{2}$ \\
\hline & 1 & $\begin{array}{l}\text { Return to the state before the } \\
\text { earthquake }\end{array}$ & 122,600 & 75 \\
\hline & 2 & Economic raising of resistance & 218,450 & 135 \\
\hline 叫 & 3 & Further raise of resistance & 533,650 & 335 \\
\hline$\sqrt{n}$ & 4 & $\begin{array}{l}\text { Execution of additional RC walls(not } \\
\text { preferred option) }\end{array}$ & 430,900 & 270 \\
\hline
\end{tabular}

The question "how to improve old masonry buildings" could be addressed in several ways, depending on the state of individual case. Application of appropriate interventions on the load-bearing structure in accordance with the individual aim of retrofitting can span anywhere from: ensuring the stability of cantilever protrusions such as chimneys, gables, etc.; stabilising the roof and connecting it with the walls; stiffening the ceiling structures in order to attain the rigid disk behaviour of the ceiling planes and connecting them to the walls; interconnecting the walls, and ensuring adequate walls to ceilings connections; increasing the shear strength of masonry walls; adding new rigid elements in the form of new masonry walls, concrete walls, steel or concrete frames; introducing the seismic insulation at the foundation level to prevent vibration input, etc.; demolition and construction of new modern structure etc. 


\subsection{Renewal of Zagreb}

Currently, European Solidarity Fund funds in the amount of about EUR 680 million have been activated for interventions on public buildings like hospitals, kindergartens, schools, colleges, institutes, and protected heritage buildings. The funds should be spent within 18 months. Invitation was sent to public institutions and religious communities to apply for projects. Applications for the production of a complete retrofitting projects are expected for about 500 buildings within the very short deadline. After the acceptance of the projects, tenders for execution should initiate. In the first phase, works on construction/reconstruction (shell building construction) should be executed and the real deadline for these works will be around 12-15 months. After that, the works on the second phase from the funds of the Recovery Fund would continue.

\subsection{Renovation of the Petrinja area}

An EU application for Solidarity Fund funds has been sent, and a significant amount is expected to be received. It is planned to start the reconstruction as soon as possible, as in Zagreb, with the proviso that family houses will most likely be built with prefabricated construction (about 4,000 houses) due to the speed of construction and the shortage in construction companies. The design and renovation of public buildings will start in parallel.

It is currently expected that around HRK 10 billion (about $€ 1.3$ billion) will be available in the next two years for projects and construction as part of the renovation of these two areas.

\section{CONCLUSION}

After Zagreb and Petrinja earthquakes, several things were experienced and noted: needs of many people had to be taken care of at the critical moment; information and the response of the cities and the state were not immediate, and too much time was spent preparing and planning instead of acting; even things that presented immediate danger were sometimes not promptly addressed; the organisation of recovery actions goes slowly and there is a risk of missing the deadlines for financial support.

Authors would therefore like to propose this three-phase approach to the repairs, retrofitting, and reconstruction of old buildings in the earthquake-stricken areas.

Phase 1 - instead of waiting for action plans, and new laws to be enacted, damage repair works should be executed as fast as possible in order to return the buildings into the state of operation. This is the most effective way to have the city up and running. However, it also lacks the improvements to structures that would raise their reliability since their basic characteristics are roughly the same as they were before the earthquake.

Phase 2 - careful valorisation of existing buildings can then help determine what is valuable, and to what extent, and what is not of particular value. This issue is haunting Zagreb for decades in the form of practices that make sure that everything is conserved as much as possible regardless of its true cultural, technical, or practical value - which has caused more assets to fall into disrepair instead of being improved.

Phase 3 - strategic implementation of integral renovation needs to be carried out, including the synergistic urban and architectural renewal. It is important to design a renovation scheme that will allow building upgrades that can raise their value and the quality of spaces in order to (financially) facilitate the implementation of the projects that can bring the critical elements of buildings architecture and technology up to modern standards. 


\section{REFERENCES}

[1] Herak, D., Dasović, I. \& Ivančić, I., Crtice iz (geofizičke) povijesti [notes from (geophysical) history]. https://www.pmf.unizg.hr/geof/popularizacija_geofizike/ crtice iz povijesti\#DBK1667. Accessed on: 2 Mar. 2021.

[2] Ivančić, I., Seizmičnost Hrvatske [Seismicity of Croatia]. https://www.pmf.unizg.hr/ geof/seizmoloska_sluzba/seizmicnost_hrvatske\#. Accessed on: 2 Mar. 2021.

[3] Pravilnik o privremenim tehničkim propisima za građenje u seizmičkim područjima. Sl. list SFRJ 39/64.

[4] Pravilnik o Tehničkim normativima za izgradnju objekata visokogradnje u seizmičkim područjima. Sl. list SFRJ 31/81, 49/82, 29/83, 20/88, 52/90.

[5] Tehnički propis za betonske konstrukcije, p. 3381, NN 139/2009.

[6] Tehnički propis za zidane konstrukcije, p. 4, NN 1/2007.

[7] Miklin, Ž., Potresi na zagrebačkom području. http://omagi.hgi-cgs.hr/Zagreb potresi.html. Accessed on: 17 Jan. 2021.

[8] Pola godine od Zagreboačkog potresa. https://www.pmf.unizg.hr/geof/ seizmoloska_sluzba/o_zagrebackom_potresu_2020/pola_godine_od_potresa. Accessed on: 28 Jan. 2021.

[9] Šavor Novak, M. et al., Zagreb earthquake of 22 March 2020 - Preliminary report on seismologic aspects and damage to buildings. Građevinar, 72(10), pp. 869-93, 2020. DOI: 10.14256/JCE.2966.2020.

[10] Hrvatski centar za potresno inženjerstvo. https://www.hcpi.hr/. Accessed on: 6 Feb. 2021.

[11] Uroš, M. et al., Procjena oštećenja građevina nakon potresa - postupak provođenja pregleda zgrada [Post-earthquake damage assessment of buildings - procedure for conducting building inspections]. Građevinar, 72(12), pp. 1089-1115, 2021.

DOI: 10.14256/JCE.2969.2020.

[12] Markušić, S. et al., Destructive M6.2 Petrinja earthquake (Croatia) in 2020 preliminary multidisciplinary research. Remote Sensing, 13(6), p. 1095, 2021.

DOI: $10.3390 / \mathrm{rs} 13061095$.

[13] Civilna zaštita RH - Potres kod petrinje. https://civilna-zastita.gov.hr/vijesti/potreskod-petrinje-3357/3357. Accessed on: 20 Jan. 2021.

[14] Bačić, M. \& Terzić, J., Pregled nekih geotehničkih problema na području Banovine pogođenim potresom M6.4, 29.12.2020. Preliminarno izvješće-, 2021.

[15] Zakon o obnovi zgrada oštećenih potresom na području Grada Zagreba, Krapinskozagorske Županije, Zagrebačke Županije, Sisačko-moslavačke Županije i Karlovačke Županije, NN 10/2021 (5.2.2021.), p. 191, 2021.

[16] Galić, J., Vukić, H., Andrić, D. \& Stepinac, L., Tehnike Popravka i Pojačanja Zidanih Zgrada, Arhitektonski fakultet Sveučilišta u Zagrebu: Zagreb, 2020.

[17] Galić, J., Vukić, H., Andrić, D. \& Stepinac, L., Priručnik za Protupotresnu Obnovu Postojećih Zidanih Zgrada, Arhitektonski fakultet Sveučilišta u Zagrebu: Zagreb, 2020.

[18] Jukić, T., Mrđa, A. \& Perkov, K., Urbana obnova: Urbana regeneracija Donjega grada, Gornjega grada i Kaptola/Povijesne urbane cjeline Grada Zagreba, Arhitektonski fakultet Sveučilišta u Zagrebu: Zagreb, 2020. 